\title{
子供の空間表象にみる住空間概念の発達 DEVELOPMENT OF CHILD'S SPATIAL CONCEPTION ON THE HOUSE REPRESENTATION
}

\author{
萩原 美智子*, 北浦 かほる**, 增田朋子***, 宮 内 美 和**** \\ Michiko HAGIWARA, Kahoru KITAURA, Tomoko MASUDA \\ and Miwa MIYAUCHI
}

\begin{abstract}
This study examined the development of spatial knowledge in a house from the model of a child's own house, using the model house kit. The experiments involved 41 children (6-14 years old). The results were as follows:

1) Examining both models' features and making procedure, children comprehend house space with interior elements such as furniture in their early developmental stage.

2) Comparing the model and the house plan, children first understand how the space is used. And children understand house space only from an inside view. In the last stage, children acquired the knowledge of a house structure by its walls.

3) Children paid attention more to plane location than to the difference of the level in a house.
\end{abstract}

Keywords: spatial representation, spatial cognition, children, house, 空間表象、空間認知、子供、住宅、

\section{1.はじめに}

子供の空間概念の発達については、Piaget を始めとして様々な研 究がなされてきた ${ }^{1}$ 。建築空間についても、現実の建物や模型空間 などを用いて多方面から研究され、前者には足立、紙野による小学 生に自宅の間取りを描かせて空間構造を求めた研究 ${ }^{2)}$ や宮本、谷 口による小学校平面のスケッチマッブと位㯰の推定から子供の認知 の歪在調べた研究 ${ }^{3)}$ などがある。また高橋、横山らは児童館のスケ ッチマップを描かせ、その表見形式から子供の空間図式を求めてい

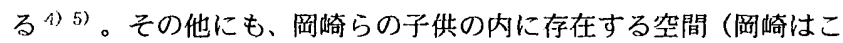
れを児童の内的世界の図式としている）の特性を解明するために、 模型で理想の学校を作らせた研究 ${ }^{6)}$ 7)があり、様々な角度から子供 の笁間認知の獲得過程が追求されてきた。これまで我々の研究室で は模型空間を用いて高さ・角度の認知 ${ }^{8)}$ や空間要素の符号化 ${ }^{9)}$ (0) 11) 12)に関する実験を行ってきた。本研究では子供の空間表象をで きる限りありのまま引き出す事によって、子供の空間概念の成り立 ちを分析し明らかにしようとするものである。空間表象とは、刺激 の存在がなく、受容器に興奮が生じないにもかかわらず、大脳中枢 の興奮にもとづいて生じる空間像で、それまでの経䮠を通して子供 の中に形成されるとされている13)。ここでは子供の中に最も定着 していると考えられる自分の家を対象として、空間表象を求めた。

\section{2.実験, 概要}

従来行なってきた実験から、模型を採用することによって低年齢 の子供を対象とすることも可能であり、分析が表現能力に影響され にくいため年跲差のある子供を比較分析しやすいという絬果を得て いたので、空間表象を取り出すには模型が最適であると考えた。実 験を始めるにあたって 6 歳児と小学 2 年生の 3 名について前研究 10）11）12）の模型を用いて予備実験を行い、その結果から被験者の年 齢、模型の縮尺、部材の種類等を再検討した。個人差が大きかった ので、小学 1 年生以上を対象とした。模型部材は壁・窓・扉・階段 の計 16 種類（135 個）と、住宅の家具類 27 種類 (77 個) を各 2 組用意した。模型部材の縮尺は全て $1 / 30$ とし、子供が扱いやすい ように磁石で自立するようにした。模型製作台は住宅の大きさを考 慮して $52 \times 52 \mathrm{~cm}$ とした。

表 1
\begin{tabular}{l|ccccccc|c}
\hline 被験者の学年 \\
\hline 学年 & 小1 1 & 小 2 & 小 3 & 小 4 & 小 5 & 小 6 & 中学 & 計 \\
\hline 男 & 6 & 4 & 0 & 3 & 1 & 0 & 0 & 14 \\
\hline 女 & 9 & 2 & 2 & 4 & 5 & 1 & 4 & 27 \\
\hline 人数 & 15 & 6 & 2 & 7 & 6 & 1 & 4 & 41 \\
\hline
\end{tabular}

\footnotetext{
* 大手前女子短期大学 非常勤講師・学修

**大阪市立大学生活科学部生活環境学科教授・学博

Part-time Lecturer, Otemae Women's Junior College, M. A.

Prof., Dept. of Environmental Design, Faculty of Human Life Science,

Osaka City Univ., Ph. D.

****侏エトス アソシエイツ

***** (侏) DOM 建築設計事務所

Ethos Associates, Inc.

DOM Architect and Associates, Ltd.
} 
赛験は被験者の前に模型部材一式を置いてその名称を説明し、ここ こに○○ちゃんのお家をつくって下さい」と言って始めた。作り終 えたことを確認した後、玄関に靴を膡くように指示した。慔型に使 われた部材は作成順に番号を付けて記録し、写真 1 ・2のように製 作途中と完了時に撮影した。被験者は小学生と中学生の計 47 名であ つたが、家の平面図を入手できた 41 名を分析対象とした。実験は 1996 年 10 月と 1997 年 9 月に、自宅以外の場所で実施した。被虽者 が居住していた住宅は、約 6 割が集合住宅で、独立住宅の居住者 17 人中 2 階建ては 13 人であった。

\section{3 空間䒾鼣の分新}

模型の完成写真をもとに $1 / 100$ の平図面を描き、部材には作成順 に番号を書き入れた。入手した各家の平面図を参考にして、模型に みられた空間表象の特徴をまとめたものが表 2 である。製作洔間は 様々であるが 30 40 分程度が多かつた。使用さ扎た部材数は個人差 が大きかったが、平均 109 片であった。また図 1 に示すように一般 に高学年になるほど使用部材数が增える傾向があり、細部まで表現 されていた。低学年で部材数が多いものは、図 2 のように複数の製 作台を使用して外周を壁で囲んだケースなどである。

1) 模型作成の着手部位

模型を作り始めた部分は、図 3 に示すような傾向がみられ、玄関 郦などの玄関周りが 4 割弱と最も多かった。次に、居間や食堂など のLD Kが約 3 割、その他に自分の部屋が 1 割強あった。家を想起 する部分は空間への入り口やL D K、子供部屋の頻度が高く、家の 中でもこれらの部分が子供の心に強く刻み込まれていることが同え た。

\section{2 ）模型の作成順序による分析}

模型に使わ㧈た部材の総数を 3 等分し、作成順序の番号より $1 / 3$ までを前期、1/3 2/3 までを中期、それ以降を後期として分析を 試みた。その結果、図 $4 \cdot 5 \cdot 6$ に示すような 3 つの作成順序がみ られた（各々の完成模型を図 $7 \cdot 8 \cdot 9$ に示す）。図 4 は、先ず前 半に家具や設借機器などの室内エレメントだけを配置し、後半に壁 をそれらの間に置いていったものである。順序I は図40ような作 り方をするのものを指し、家具を置くことで空間を表現し、室内工

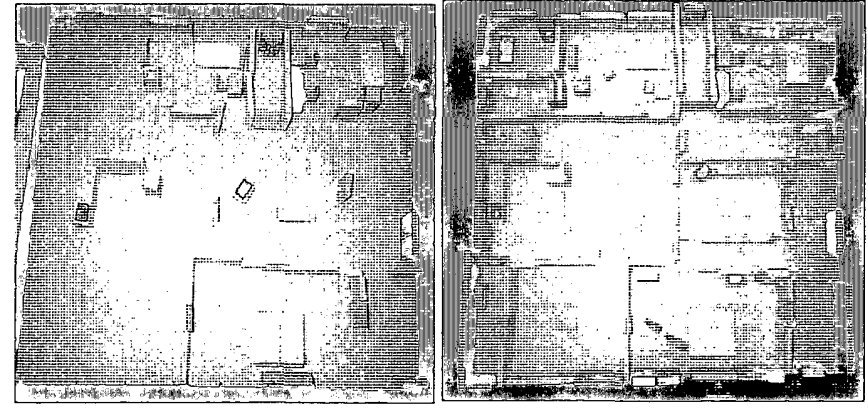

写真 1 作成途中

写真 2 完沷橴型

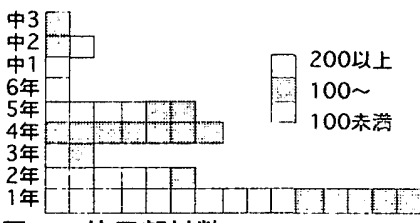

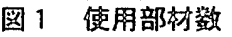

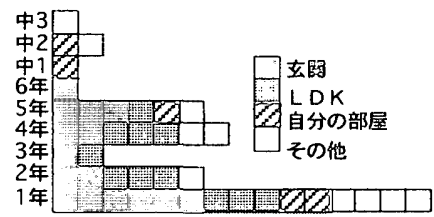

图 3 作り蛞的た部分

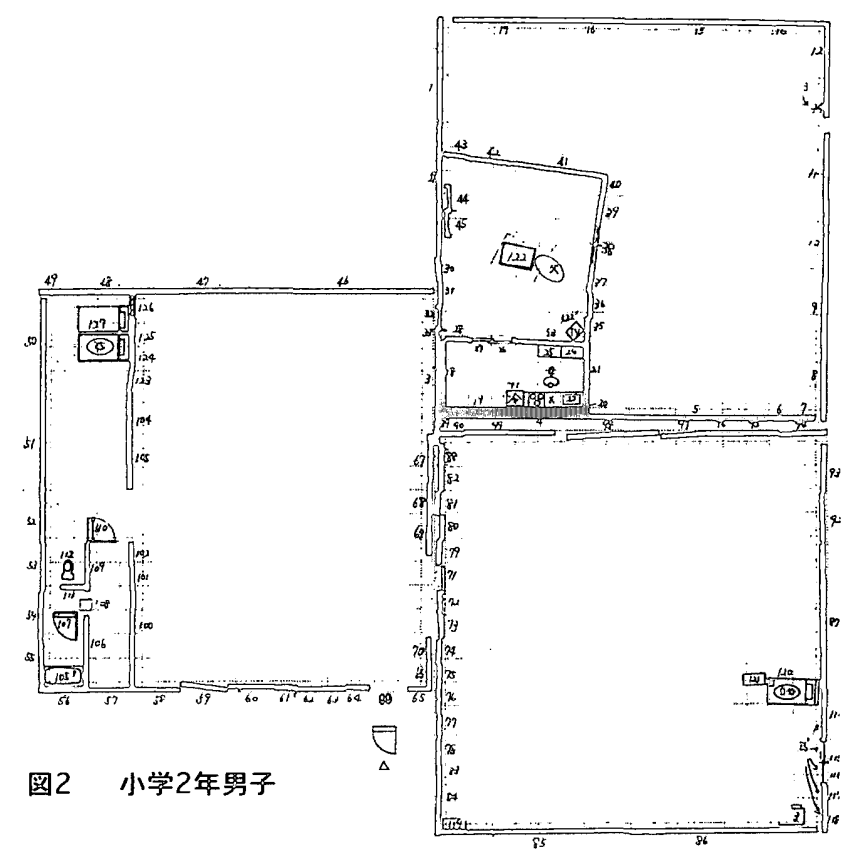

表 2 空間嶅酦の待徵

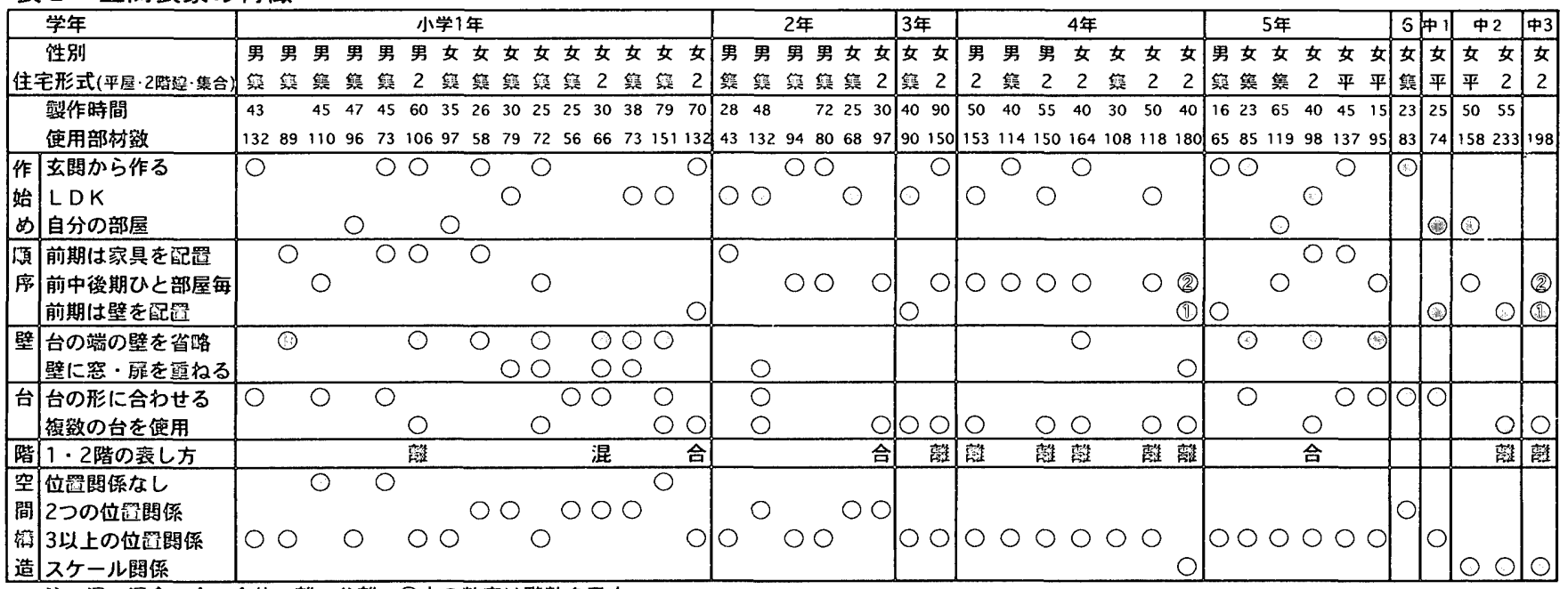

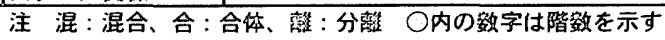


レメントで空間を想起していると考えられる。子供の注意は空間要 素の中でも室内装備に向けられていることが伺え、家具類を手がか りにして空間を理解している様子が分かる。また順序【はは図 5 に示 すように、前中後期とも家具と壁を用いながら部分毎に順次作って いくものである。順序II は空間を内部からの視点で、家具と壁の空 間要素を備えた部分として捉えていることが同える。順序IIIは図 6 の例に示すように前半に壁だけで部屋構成を作ってしまい、その後 に壁で構成した室内に家具を配置している。順序IIIで作る子供は家 を既に壁による空間構成として捉えることができている。壁構成と 内部エレメントを切り離して捉えることが可能になっており、空間 構成や内部空間の状況が十分に理解できていると考えられる。

以上のように、模型の作成順序を巡ることによって子供の思考過 程を推察することができ、子供の空間の捉え方を顕著に示す I・II ・ IIIのタイブを見つけることができた。これ以外の作成順序は I ・ II ・ IIIの変形や複合タイブと考えられるものであった。また I や II には 表現が不完全であったり稚拙なものがあり、IIIには完成度の高いも
のが多くみられた。図10 は作成順序を学年別にみたものである。 大勢としては年齢が高くなるにつれて順序 I 的な理解から順序III的 な捉え方へ移行する傾向にあるが、1 年生の中にも而の者がみられ、 個人差の要因も大きいと考えられる。

3）壁の表現

壁の表現には図 11 に示すように、壁の前に更に空を重ねて置く ものがみられた。作成順序をみると壁を配置した後に家具と共に室 内側に空を置いていることが分かる。これは空や扉は開閉という行 為と関係があることや目に付きやすいなど、家具との類似点の方が 多いためであろう。このような壁の表現は図 12 に示すように主に 低学年に夕ら㧈、空や郦を壁から分離させる捉え方は空間要素の初 期的な捉え方といえる。壁表現では他に、製作台端の壁を省略する 傾向がみられた。子供は台を家の領域と見なし、あえて境界を示す 壁を置く必要がないと考えたのであろう。他に製作台については、 台の形に合わせて家を表現したものがあり、これは䒾 2 に示すよう に年齢に関係なくみら扎た。教示の仕方が子供に1つの方向性を示

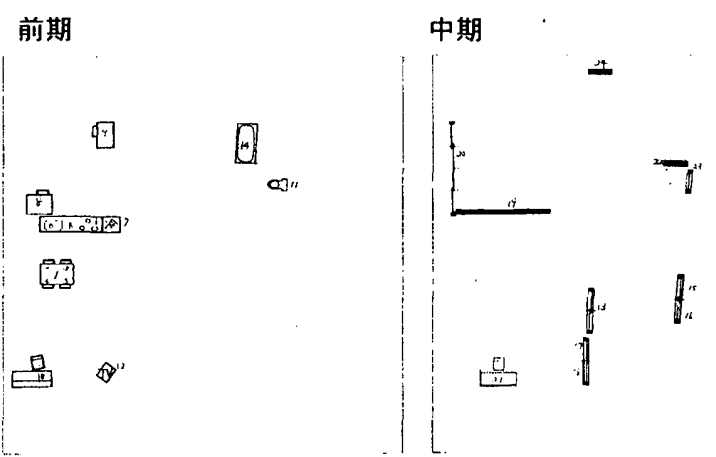

図4 作成順序 | 小学2年男子

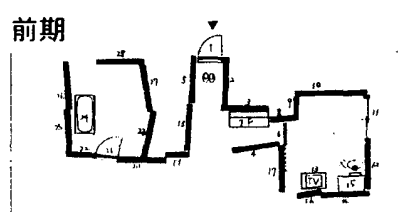

図5 作成順序 || 小学2年男子

前期

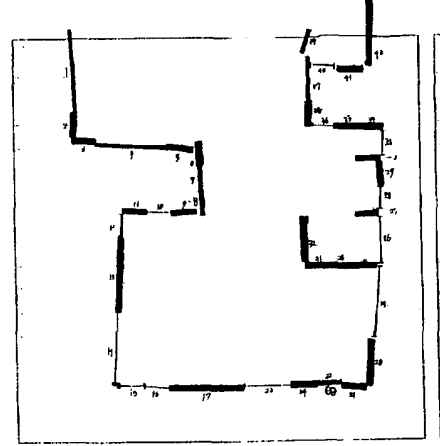

図6 作成順序 III 中学2年女子

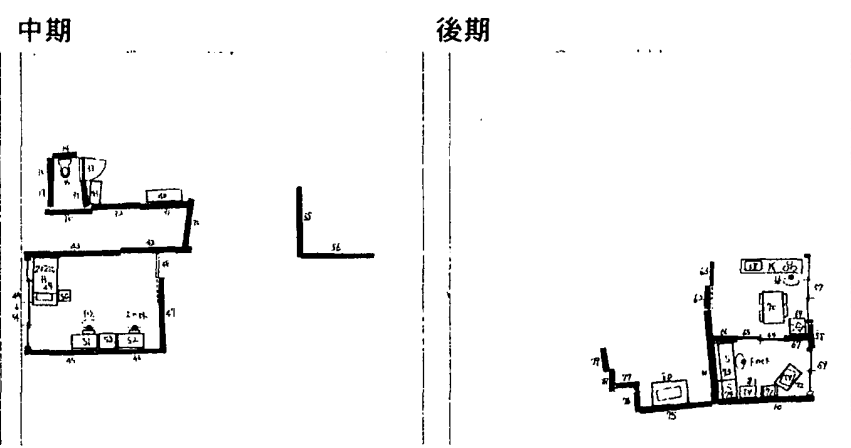

後期
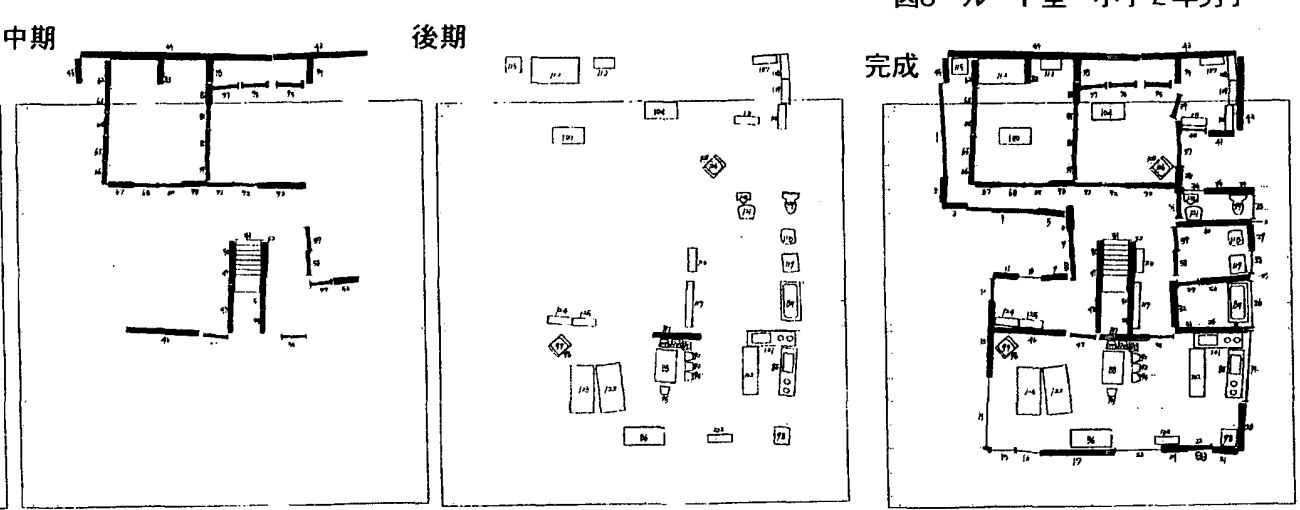

図9 サーヴェイ型 中学 2 年女子 
㖫する可能性があり、本実験についても文脈の影響は免れないと思 われる。上記の台の使い方については子供にはもともと家を一つの 限られた空間領域と捉える側面があって、その領域を台で代用した ためと考えられる。これ以外に家の外形が方形に近いので、台の形 を利用したものもあった。

4） $1 \cdot 2$ 階の表現

1 階と2 階の表現については、奏際の空間のように 2 階を 1 階の 上に作ることはできないが、子供がどのように対処するか牢動も含 めて把握することが目的であった。図 13 は一見ごく普通にみえる か、，2階建て住宅にもかかわらず、階段はなく2階の部屋と 1 階の 部屋が陊接し、 1 階に 2 階の部屋を嵌め込むように作られていた。 壁で空間を区切りながら目印となる家具を壁に沿って置いており、 作成順序はI とII の中間であった。1・2 階を順不同に作っていき、 台全体に 1 階と 2 階を混在させて表現していた。この子供には階数 の違いより、各部屋での日常的な行為が強く刻多込まれているため このような表現をしたと推察される。1・2階を混在させた表現は、 この子供にだけみられたものであった。また図 14 のように 1 階と 2 階の境の壁を共有させて、同じ平面上に作った子供がいた。 $1 \cdot 2$ 階を合体させた表現は、全部で 3 例みられた。住空間のように日常 的に熟知している空間については、階数より部屋の相互関係の方が 子供の意識に上りやすいのではないかと考えられる。その他には、 模型作成時に 1 階の模型の上に 2 階の床をのせたいと言う子供がい た。 1 - 2 階の空間領域の捉え方については、空間の理解の代方や 各部犀の位置関係の把握などと関連しながら発達していくものと考 えられる。

\section{5）空間表像の類型}

完成模型の表現には、子供の空間把握状況を示寸幾つかの類型が みられた。まず図 7 や図 15 にみられるように、主に家具や設備機 器で空間を表現するものである。壁が非常に少なく、家を家具で象 徽的にあらわしていたので家具象徽型とした。この型の作成順序は 順序 I であり、家具で空間を想起していた。図 7 の子供は布団を入 れる所と言って押入の場所に布団を置き、空間を使い方で認識して いる様子が同えた。家具等の室内装備は空間の中で行われる人の行 為を示すものであり、この型の子供は空間を用途に注目して捉えて いると考えられた。次に、図 8 のように室内からの視点で捉えてい るものがあった。実際には壁一枚で区切られている部屋と部屋との 間に隙間のような空間ができていて、洞窟のように見える。このタ
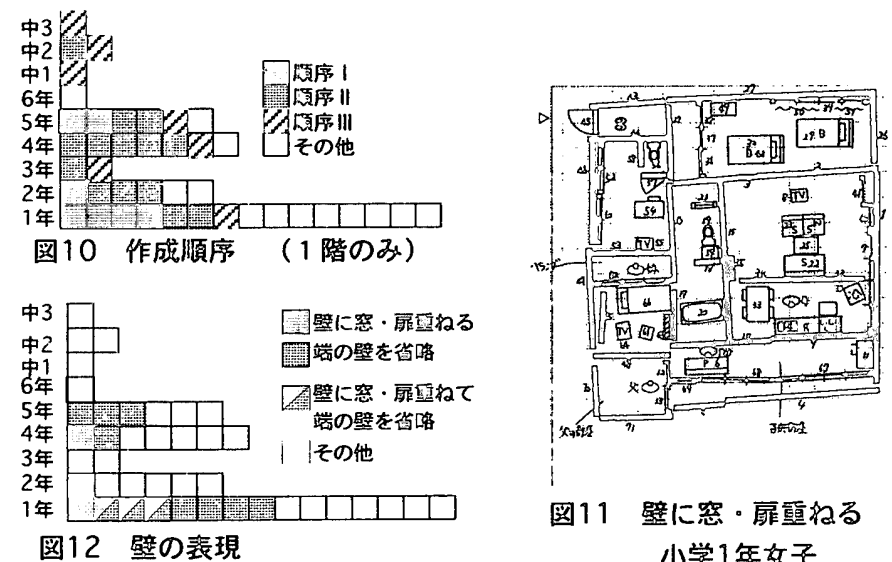

图11壁に空・扉重约る 小学1年好子
イプは内部視点だけで捉えていることが分かる。作成順序はIIであ り、家の中を順に内部視点で部分的に捉えているのでルート型 (1) とした。特に集合住宅のように家の外形を目にすることができない 場合には、このような捉え方になりがちと考えられる。最後に図 9 のように平面図に近いものがみられした。前述の2つの型とは異なり 完成模型からは何を手がかりにしているのか読みとり難い。しかし、 作成順序をみると四であり、家を壁構成で理解できていることが分 かる。壁構成として家を平面図的に捉えら扟る段階は、様々な空間 体験や学習によって筀間理解が深めら扎結㷊であり、サ一ヴェイ 型 15) と名付けた。

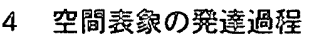

1）空間婊象の類型と模型作成順序の関係

前述のように完成模型の型には子供の空間の捉え方を端的に示す ものがあり、典型例とみられるものは空間の捉え方が模型作成順序 にも反映さ机ているものであった。完成模型が類型的であり更に作 成順序が明確にそれを塞付けているものだけを抽出すると少数にな るが、作成された模型空閒からそれでれの空間表象の類型と作成過 程の指向性を伺うこ上ができた。この 2 つの指標を手がかりに分析 していくことによって、子供の空間把握の晛状を明らかにできると 考えた。例えば図 16 は家具やカーペットで部屋や廊下をあらわし ており多分に家具象徽的であるが、作成順序は II であることからル 一ト型的な捉え方も併せ持つことが分かる。この例のように家具象 徵型とルート型の双方の傾向を持つものが多くみられた。また図 17 や図 18 は表現形式はサーヴェイ型に近いが、作成順序をみると図 17 は順序 I であり、家具像徽型的な捉え方をしていることが分かる。 同様に図 18 は順序IIでルート型的な傾问がみられる。これらの例

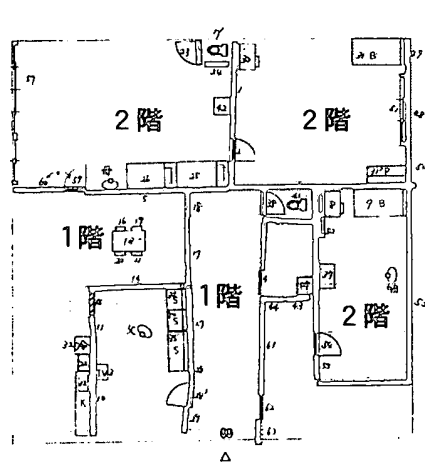

图131.2管混在 小学 1 年好子

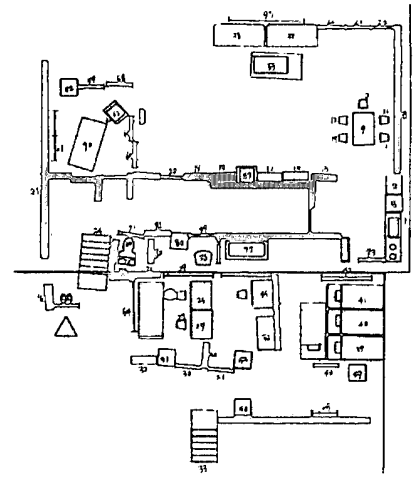

図14 1 - 2 階合体 小学5年女子

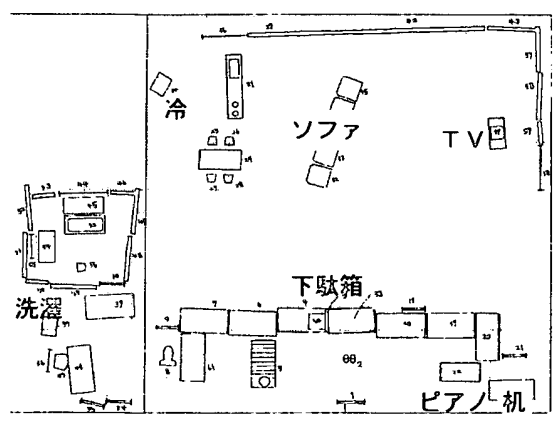

图15 家具皱徵型 小学1年男子 
から、家具象徽型やルート型が発達してサーヴェイ型になっていく ものと思わ扟る。

2）位置関係の成立からみた発達過程

空間表象の類型と作成順序からえた子供の筀間把握の状況を更に 詳細にみるために、現実空間の再現性を指標に分類し位置づけてみ たのが図 19 である。子供の作った慔型と現実の住宅平面図の比較 から隣接する部屋の関係がどのように捉えられているかを、a 関係 性なし、b2つの関係性の成立、c 3つ以上の関保性の成立、d 位置 関係とスケール感の成立の段階に分けて、各サンブルを位置づけた。 位置づけの相対関係をできるだけ正確に捉えるために、それでれの 段階を達成前期と後期に 2 分して考えた。a 関係性なしは家具が無 関係に置かれるものを前期、部屋のまとまりを持つものを後期とし て考えた。b以降の段階については、その段階に達していると考え られるが部分的にできていない所があるものを前期、その関係が完 全にできているものを後期とした。 c d 間の達成状沙は他と比べ複 雑になり達成までの過程が多様であったため前期と後期をさらに 2 分し、前期 1 は 3 つの関係性の成立段階に達しているがまだ部分的 なもの、前期 2 は 3 つの関倸性はほぼ成立しているもの、後期 1 は 3 つ以上の部屋の関係性は完全に成立しているが全体的にはまだ不 完全なもの、後期 2 は全ての部屋関係はほぼ成立しているがまだス ケール感は表現されていない段階として捉えた。また、縦軸には典 型的な表象の型を位置づけ、サーヴェイ型は家具象徵型とルート型 のいずれにも源流をもつ状況が伺えたためその中央に位置づけた。 各型の典型例を軸線上に設定し、2つの傾问を持つものは軸の間に それ以外は近似する軸の外側に、傾向の強いものほど軸近くに配置 した。

家具象徵型の典型は 3 つ以上の関係の成立前期に、ルート型の典 型はその後期にみら扎。サーヴェイ型がみられるのはスケール感 の成立段階以降であった。しかし、比較的早い段階から家具象徵と ルート型傾向を合わせ持つものがみられる。家具象徴型をとるかル 一ト型をとるかは個人の空間の捉え方の差であり、それらがサーヴ エイ型に収斂していく状海が分かる。作成順序でみると、順序 I の 分布は $\mathrm{c} \mathrm{d}$ 間の後半には家具象徵型軸から離九、家具で理解するも

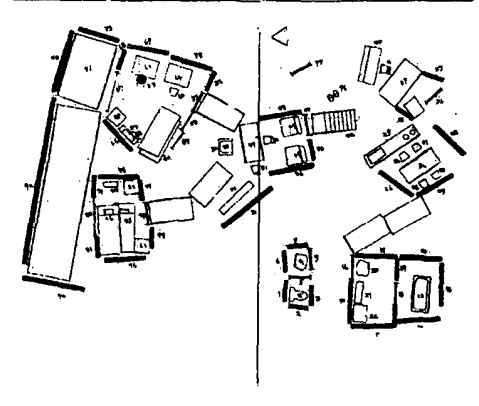

図16 小学 2 年女子 (順序 II)

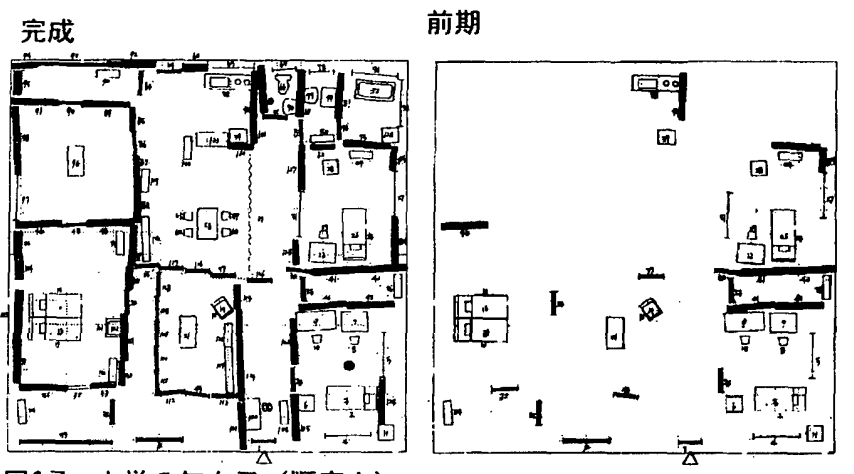

図17 小学 5 年女子 (順序 1)

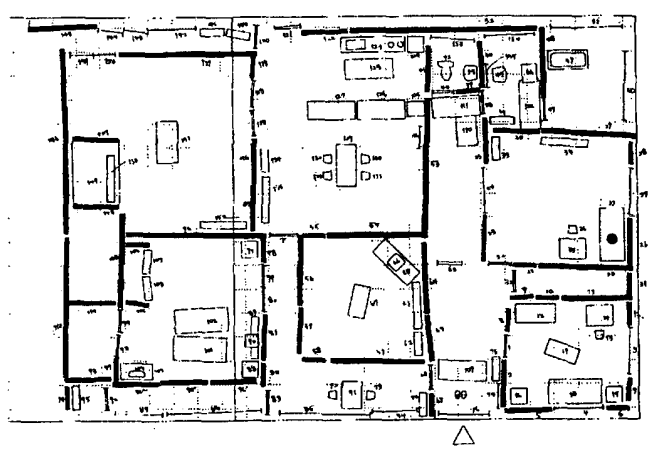

図18 中学 2 年女子 (順序 II)

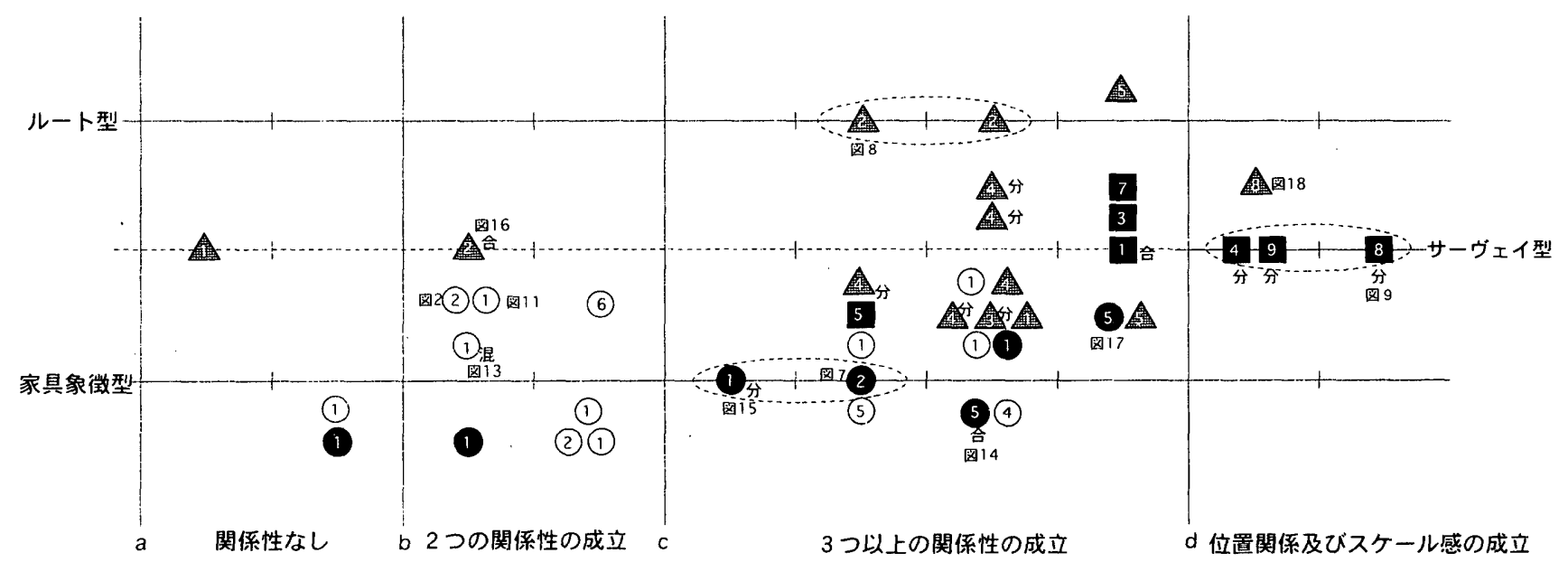

図19 空間表象の型と空間把握の段階

凡例 順序!

A順序川 混 : $1 \cdot 2$ 隆混在 番号は学年、中学生は7 9

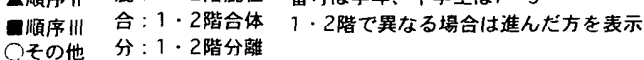


のも段階が進むにつれて他の捉え方が加わっていくことが何える。 順序 II は比較的とりやすいと考えられる順序であるため様々なもの が含まれるが、最終段階ではサーヴェイ型に近づく。思考過程を分 析すると住空間においては家具象徵型的な捉え方が発達段階の後半 までみられることが分かり、こうした見方は住空間が子供の良く知 っている空間であるという特質と関係があると考えられる。

住空間の平面配置と階数の捉え方の関係をみると、2 室の関係が 表現される段階には、1・2 階の部屋が区別されずに混在するもの と、1・2 階を 1 つに連続させて作った例がみられた。住空間にお いては一般的に平面的な位置関係の方が階層の区分より強く意識さ れていると考えられる。また 3 室以上の関係が表現される段階にな つても、1・2 階を連続させて 1 つの模型として表現した子供が 8 人中 2 人いた。 3 つの部屋の位置関係は把握できていても階数の捉 え方にはばらつきがみられる。これには住宅形式の差や階数による 部屋の使用頻度の差などが反映されており、子供の今までの生活体 験で空間認識に差が生じている結果と思われる。住空間内での子供 の生活は各部屋での行為が連続的に繰り広げられるものであり、子 供と空間との係わり方も密接である。このような空間の特質が、部 屋相互の関係と階層の区分に関係すると考えられ、質の異なる空間 との比較が必要である。子供の住空間の理解レベルは非常に大きく みれば曆年龄に対応しているが、対象とする空間の質や子供の空間 経験などの個人差にかかわる要因が大きく影響していると考えられ る。

\section{5 まと的}

子供の最もよく知っている住空間を対象として模型を作成させる ことから空間表象を求めた結果、以下のことが分かった。

1) 子供の空間把握の初期の段階は、家具や設備機器といつた室内 の装備で住空間を捉えていることが分かった。

2）子供の住空間表象には家具象徵型とルート型とサーヴェイ型の 3 つの典型例がみられた。家具象徵型は 3 つ以上の空間の関係性の 成立前期に、ルート型はその後期にみられ、そのいずれのタイプを とるかは個人の空間の捉え方の差が関係する。また、それらは発達 に伴いサーヴェイ型に収斂していく。

3) 住空間の階数表現には、住宅形式や階数による部屋の使用頻度

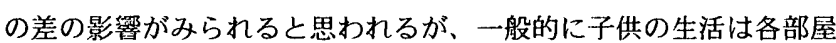
で連続的に行われるため、部屋の位置関係の方が階数の違いよりも 意識されやすく、2 層の住空間は連続して 1 層として表現されやす い。また、階数の理解は建物の規模や形態で大きく異なってくる。 4）子供の住空間の理解には、年齢による発達を越えた個人差が大 きくみられた。子供の空間に対する興味の持ち方や子供の空間体験 などが、こうした個人差を生じさせているものと推察できる。

謝辞 調查にご協力いただいた、児童ならびに保護者の皆様や先生 施心り感謝いたします。また本研究は卒論生の玉村玲子氏との 共同研究であることをここに記して感謝の意を表します。

註記

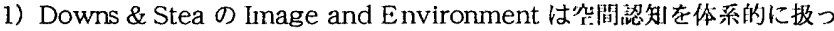

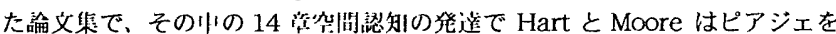
始めとして、それまでの作究のレビューを行なっている。 Downs \& Stea

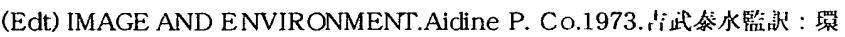
境の贺䦌的イメージ、麇战出版会 $\mathrm{p} 266$ 312.1976.

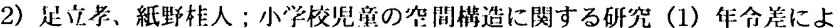

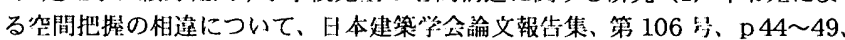

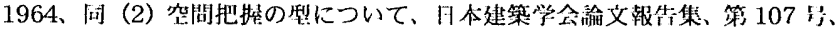
p 54 59、1965、

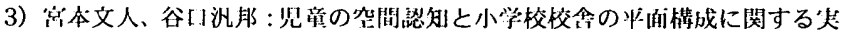

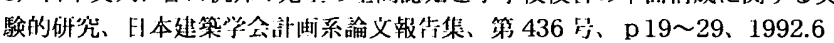

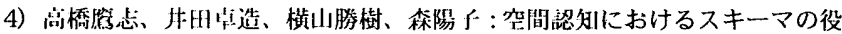

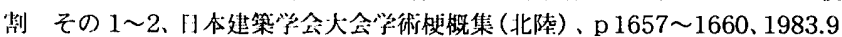

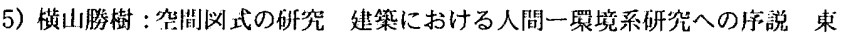

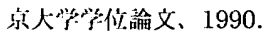

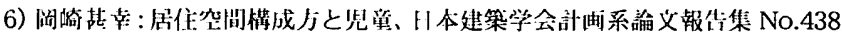
㧒, p 109 118、1992.8

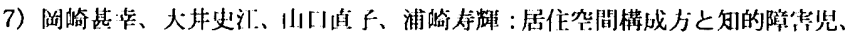

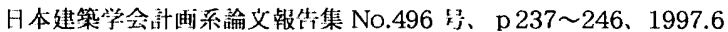

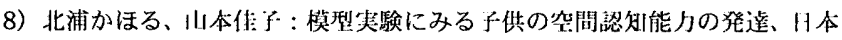
建勧兴会近畿支部研究報告集、p 517 520、1994.6

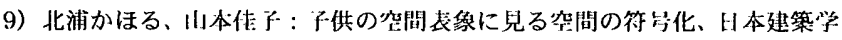
会近畿支部研究報生集、建策学会近畿支部、p 521 524、1994.6

10）北浦かほる、野中仍与：模型による子供の空間認知に閉する研究、U会 建勧学会近戴支部研究報告集、 $\mathrm{p} 305 \sim 308 、 1995.6$

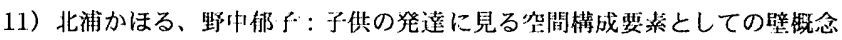
の理解U本建築学会近畿支的研究報告集、p 309 312、1995.6

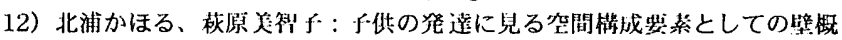

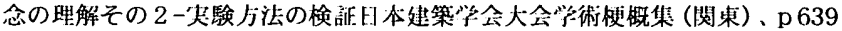
$\sim 640 、 1997.9$

13）心理学辞典 被心䓪房 p 383 .

14）シュミヤキン (Shemyakin, F. N., 1962) は、大規模究間である地形的 戈象には、ルート・マップ(route map) 型とサーヴェイ・マッブ(survey map)

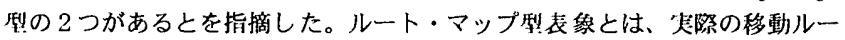
卜を心的にたどることによって啨成される系統的な表像であり、サーヴェ

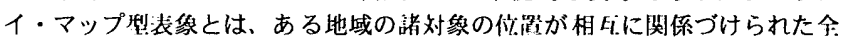
作的な战象をさしている。住究間表缘は地形的表象のような大スケールを対 缘とするものではないが、建物を内部視点で捉えており移動ルートを心似に たどる点でこの用望を用いた。

15）间様に建物内蔀の部屋を相たに䍘係づけ全体的に捉えている点で、サー ヴェイ型とした。

（1998年 9 月 10 日原稿受理，1999年 2 月 2 日採用決定） 